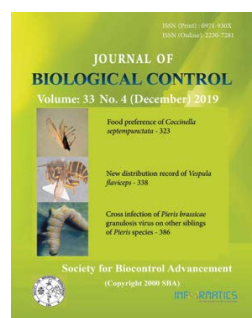

\title{
Cross infection of Pieris brassicae granulosis virus on other siblings of Pieris species
}

\author{
R. VARATHARAJAN ${ }^{*}$, W. SANGEETA ${ }^{1}$, H. SARJUBALA ${ }^{1}$, P. H. SUJATA ${ }^{1}$ and R. R. RACHANA ${ }^{2}$ \\ ${ }^{1}$ CAS in Life Sciences, Manipur University, Imphal - 795003, Manipur, India \\ ${ }^{2}$ Division of Germplasm Collection \& Characterization, ICAR-National Bureau of Agricultural Insect Resources, Bengaluru - \\ 560024, Karnataka, India \\ *Corresponding author E-mail: rvrajanramya@gmail.com
}

\begin{abstract}
Pieris brassicae granulosis virus (PibrGV) has been found to infect yet another two siblings namely $P$. canidia Linn. \& Pontia daplidice (=Pieris daplidice) (Roeber) in addition to P. brassicae (Linn.). The susceptibility of $P$. canidia and $P$. daplidice has been established clearly in this work by inoculating them with PibrGV@ @ $\times 10^{4}$ occlusion bodies (OBs) per ml by the conventional leaf disc method. All the inoculated larvae exhibited typical symptoms of viral infection after 5-7 days of post infection. The above three species of the genus Pieris occur on cabbage and cauliflower plants at different periods in the valley region of Imphal and therefore, it is possible to control all the three species of Pieris using the same virus. $\mathrm{LC}_{50}$ value of PibrGV on P. brassicae, P. canidia and P. daplidice was found to be $7.9 \times 10^{4} ; 10 \times 10^{6} ;$ and $6.3 \times 10^{6} \mathrm{OBs} / \mathrm{ml}$ and the $\mathrm{LT}_{50}$ was $134.89 ; 138.03 ; 174.50$ hours, respectively.
\end{abstract}

KEY WORDS: Cross infection, granulosis virus, Pieris canidia, Pieris brassicae, Pontia daplidice

(Article chronicle: Received: 26-07-2019; Revised: 12-11-2019; Accepted: 25-11-2019)

Pieris brassicae (Linn.) is a cosmopolitan oligophagous pest and invariably infests vegetable crops belonging to the family Brassicaceae. Although the large cabbage white, $P$. brassicae is very common in NE India, occurrence of species such as Pieris canidia Linn. (Indian Cabbage white) and Pontia daplidice moorei (=Pieris daplidice) (Roeber, 1907) (the bath white) was also noticed in the valley districts of Imphal $\left(24.7523^{\circ} \mathrm{N}, 93.9280^{\circ} \mathrm{E}\right)$, Manipur. Among the winter vegetables, cabbage and cauliflower are cultivated in Manipur in an area of 7600 and 2570 ha with the production of 91,000 and 26,000 MT respectively (DAC, 2017; NIFTEM, 2012-13; Ashwini et al., 2017) and they occupy an important status in the agro-economy of the state. A study on the insect pests infesting cauliflower and cabbage revealed the occurrence of nearly two dozen pest species belonging to five orders and 12 families with varying intensity of attack and period of activity during three seasons viz., early, mid and late varieties of cabbage and cauliflower (Bijaya, 1998; Devjani, 1999). Among them, cabbage butterfly is one of the serious pests of mid and late crops cultivated from September to March in Manipur. It causes crop loss to the tune of 8 to $31 \%$ at different periods in Uttarakhand but the infested localized cabbage head has shown cent percent infestation as the adult moth lays eggs in cluster on the same plant. It has also been estimated that single larva has been found to consume $80 \mathrm{~cm}^{2}$ area of cabbage leaf during the larval period (Arun et al., 2017). To control the caterpillars of P. brassicae, a specific granulosis virus- $P i b r \mathrm{GV}$ has been found effective (Varatharajan, 2008; Sangeeta et al., 2009). While evaluating PibrGV against $P$. brassicae under the field condition, it was noticed that two other siblings namely $P$. canidia and $P$. dapladice were also infected by $P i b r \mathrm{GV}$ in addition to $P$. brassicae. Therefore, an attempt has been made in the present work to confirm the cross infectivity of the virus on other species of Pieris.

With the aim to confirm the cross infectivity, uninfected caterpillars (3rd instar) of P. brassicae, P. canidia and Pontia daplidice (=Pieris daplidice), were inoculated with Pieris brassicae granulosis virus (PibrGV)@ $5 \times 10^{4}$ occlusion bodies (OBs)/ml by conventional leaf disc method (Rabindra et al., 1997). To start with the experiment initially the field collected healthy larvae of $P$. brassicae were inoculated. The OBs obtained from $P$. brassicae were used to inoculate the larvae of $P$. canidia and $P$. daplidice individually. Subsequently, the OBs isolated from the cadavers of $P$. canidia and $P$. daplidice were used against fresh caterpillars 
of $P$. brassicae to check whether these OBs collected from the two siblings work or not. This process of serial passage was repeated twice to confirm and establish the cross infectivity of $P i b r \mathrm{GV}$ on the three insect hosts.

\section{Lethal concentration}

To assess the lethal concentration, uninfected normal caterpillars $\left(3^{\text {rd }}\right.$ instar) of $P$. canidia and Pontia daplidice (=Pieris daplidice), were inoculated with different concentrations ranging from $10^{3}$ to $10^{7} \mathrm{OBs}$ per $\mathrm{ml}$ of PibrGV by conventional leaf disc method (Rabindra et al., 1997). There were five treatments /concentrations as said above and each treatment was replicated three times. In the case of $P$. brassicae, as many as 150 larvae were exposed (a) 10 individuals per replication, while 45 larvae each were inoculated for $P$. canidia and $P$. daplidice due to their less abundance in comparison to $P$. brassicae. In this method, $4 \mathrm{~cm}$ diameter young cabbage leaf was cut in a circular fashion (leaf disc). The virus suspension was applied @ $100 \mu \mathrm{l} /$ leaf disk and and spread on the leaf disc with the help of insect collecting small camel brush and on air drying, the leaf disc was kept individually inside the petriplate. The $3 \mathrm{rd}$ instar larvae collected from the stock culture were starved for 4 hours and then released on the leaf disc. After consumption of the entire leaf disc the larvae were reared uniformly inside the plastic jar $(20 \mathrm{~cm}$ height $\times 10 \mathrm{~cm}$ diameter) for each treatment separately. Daily observation was taken till the death of all the inoculated larvae. The larval mortality recorded under different concentration of virus treatment was subjected to Probit analysis (Finney, 1977) and the data were provided in Table 1. In order to calculate the lethal time, the $3^{\text {rd }}$ instar larvae of each species was inoculated with the respective $\mathrm{LC}_{50}$ dose of OBs obtained in the lethal concentration studies. After inoculation, the caterpillars were reared as stated above and the mortality rate was noted every day. The relation between time factor and larval mortality was also processed for Probit analysis (Table 2).

PibrGV was tested against the caterpillars of Pieris canidia and Pontia daplidice (=Pieris daplidice). All the inoculated larvae exhibited typical symptoms of viral infection after 5-7 days of post infection. Initially the larvae showed sluggishness, reduction in food intake and cuticle became very shiny, fragile, and loose and eventually ruptured liberating a milky fluid which consisted of thousands of OBs. At the last phase they hang upside down with their caudal legs. Experiments unequivocally demonstrated that the two closely related species of Pieris namely P. canidia and $P$. daplidice were found susceptible to PibrGV. The larvae of both the siblings exhibited similar symptoms of viral infection as like that of $P$. brassicae (Fig. 1). To confirm the susceptibility, reciprocal cross experiments were conducted. Such combination of trials unambiguously proved the cross- infectivity traits of $P i b r \mathrm{GV}$. The advantage of this experiment is that the same virus (PibrGV) can be used for the control of all the three species of Pieris caterpillars in the cabbage fields. Sangeeta and Varatharajan (2011) have studied extensively the Granulosis Virus (GV) infecting P. brassicae. This GV is known to cause cross infection on $P$. rapae (Charles et al., 1981; Entwistle, 1998). Crook (1981) made a comparative study on the GV infecting P. brassicae and P. rapae. However, this is the first report concerning cross infection of PibrGV on Pieris canidia and P. daplidice.
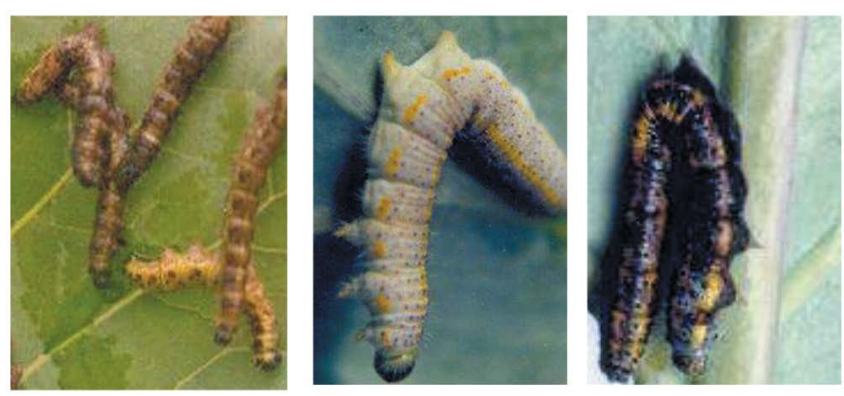

Fig.1. PibrG $V$ infected larvae of Pieris brassicae, Pieris canidia and $P$. daplidice.

In addition to the cross infectivity, $\mathrm{LC}_{50}$ as well as $\mathrm{LT}_{50}$ was also calculated for all the three species of Pieris and the study reflected $\mathrm{LC}_{50}$ value of $7.9 \times 10^{4} ; 10 \times 10^{6}$; and $6.3 \times 10^{6}$ $\mathrm{OBs} / \mathrm{ml}$ and the $\mathrm{LT}_{50}$ value was $134.89 ; 138.03 ; 174.50$ hours, respectively, for $P$. brassicae, $P$. canidia and $P$. daplidice. The $\mathrm{LC}_{50}$ of $P i b r \mathrm{GV}$ was found to be significantly lower in $P$. brassicae in comparison to P. canidia and $P$. daplidice, which could be attributed to the effect of pathogen on primary as well as secondary insect hosts respectively. Similarly, $\mathrm{LT}_{50}$ value of the pathogen was numerically much lower among the individuals of $P$. brassicae than the other two alternate hosts. It is well known that the primary host is always vulnerable to pathogen much quicker than the secondary host (Smith, 1976). Therefore, in the present study too, the primary host $P$. brassicae showed quick susceptibility and that being reflected in the $\mathrm{LC}_{50}$ as well as $\mathrm{LT}_{50}$ (Table 1 and 2). Even though, there seems to be certain variation in terms of susceptibility among the three species of Pieris, the field control of all the three species of Pieris can be achieved by spraying the PibrGV @ $7.5 \times 10^{8} \mathrm{OBs} / \mathrm{ml}$. This is apparent in the earlier field trials carried out prior to confirmation on their cross infectivity (Sangeeta, 2011; Sangeeta and Varatharajan, 2011).

Cross infectivity of granulosis virus has been recorded among the close siblings of certain leidopteran insects. As for instance, the granulosis virus infecting Chilo infuscatellus Snell is known to infect yet another closely related sugar cane borer, Chilo sacchariphagus indicus (Kapur) (Easwaramoorthy and Jayaraj, 1987). Similarly, the GV infecting Agrotis segetum (AgseGV) was found effective to 
Table 1. Lethal concentration of PibrGV on the larvae of three species of Pieris

\begin{tabular}{|l|c|c|c|c|}
\hline $\begin{array}{l}\text { III instar } \\
\text { larvae of }\end{array}$ & $\begin{array}{c}\text { Regression } \\
\text { equation } \\
\text { (based on } \\
\left.\mathrm{LC}_{50}\right)\end{array}$ & $\begin{array}{c}\mathrm{LC}_{50} \mathrm{OBs} / \\
\mathrm{ml}\end{array}$ & $\begin{array}{c}\mathrm{LT}_{10} \\
\mathrm{OBs} / \mathrm{ml}\end{array}$ & $\begin{array}{c}\mathrm{LT}_{90} \\
\mathrm{OBs} / \mathrm{ml}\end{array}$ \\
\hline $\begin{array}{l}\text { Pieris } \\
\text { brassicae } \\
(\mathrm{n}=150)\end{array}$ & $\begin{array}{c}\mathrm{Y}=0.605 \times \\
+1.94\end{array}$ & $7.9 \times 10^{4}$ & $9 \times 10^{2}$ & $8.85 \times 10^{6}$ \\
\hline $\begin{array}{l}\text { Pieris } \\
\text { canidia } \\
(\mathrm{n}=45)\end{array}$ & $\begin{array}{c}\mathrm{Y}=0.50 \times \\
+1.48\end{array}$ & $10 \times 10^{6}$ & $3 \times 10^{4}$ & $3.9 \times 10^{8}$ \\
\hline $\begin{array}{l}\text { Pontia } \\
\text { daplidice } \\
(\mathrm{n}=45)\end{array}$ & $\begin{array}{c}\mathrm{Y}=1.06 \times \\
+(-3.27)\end{array}$ & $6.3 \times 10^{6}$ & $3.8 \times 10^{5}$ & $10 \times 10^{8}$ \\
\hline
\end{tabular}

n - indicates number of larvae inoculated. Five different concentrations (treatments) ranging from $10^{3}$ to $10^{7} \mathrm{OBs}$ per $\mathrm{ml}$ and three replications for each species. In the case $P$. brassicae 10 larvae/replication and for Pieris canidia \& P. daplidice 3 larvae/ replication were inoculated

Table 2. Relation between lethal time (LT) and mortality rate of Pieris

\begin{tabular}{|l|l|l|l|l|}
\hline $\begin{array}{l}\text { III instar } \\
\text { larvae of }\end{array}$ & $\begin{array}{l}\text { Regression } \\
\text { equation } \\
\text { (based on } \mathrm{LT}_{50} \text { ) }\end{array}$ & $\begin{array}{l}\mathrm{LT}_{10} \\
\text { (hours) }\end{array}$ & $\begin{array}{l}\mathrm{LC}_{50} \\
\text { (hours) }\end{array}$ & $\begin{array}{l}\mathrm{LC}_{90} \\
\text { (hours) }\end{array}$ \\
\hline $\begin{array}{l}\text { Pieris } \\
\text { brassicae }\end{array}$ & $\begin{array}{l}\mathrm{Y}=7.20 \mathrm{x}+ \\
(-10.4)\end{array}$ & 89.12 & 134.89 & 204.17 \\
\hline $\begin{array}{l}\text { Pieris } \\
\text { canidia }\end{array}$ & $\begin{array}{l}\mathrm{Y}=7.25 \mathrm{x}+ \\
(-10.5)\end{array}$ & 91.20 & 138.03 & 204.20 \\
\hline $\begin{array}{l}\text { Pontia } \\
\text { daplidice }\end{array}$ & $\begin{array}{l}\mathrm{Y}=15.48 \mathrm{x}+ \\
(-29.7)\end{array}$ & 141.25 & 174.50 & 211.15 \\
\hline
\end{tabular}

Five replications each with 10 larvae for each species ( $\mathrm{n}=50$ individuals for each species); $\mathrm{LC}_{50}$ value mentioned in table -1 was used for inoculation of the respective species of Pieris

A. ipsilon (Shah et al., 1979; Zethner et al., 1987). As early as 1981 Piers rapae was known to be susceptible to PibrGV (Charles et al., 1981). Although the genome sequence of GV infecting $P$. rapae has not been compared with that of GV affecting the three Pieris species in India, it is expected that the same GV would be influential in bringing down the density of all the four cruciferous pest species such as Pieris brassicae, P. canidia, P. daplidice and P. rapae. The propensity of pathogen's co-infection with secondary and tertiary hosts could be due to synchronous occurrence of such pests along with the primary pest species on the same or related plant species belonging to the same plant family. Therefore, the long-term association and co-occurrence of siblings in a micro-habitat facilitate the secondary/tertiary hosts to acquire the susceptibility trait. This is evident in the examined systems whether it is sugarcane or cabbage. Nevertheless, the ultimate advantage of co-infection leads to natural regulation of closely related pests by a single pathogen so that its dissemination paves way for survival of GV on alternate hosts.

\section{ACKNOWLEDGEMENT}

The authors are grateful to the Co-ordinator, CAS in Life Sciences, Manipur University for the encouragement.

\section{REFERENCES}

Arun D, Singh, KI, Gupta, MK, Sobitadevi, P. 2017. Biorational management of major lepidopterous pests and their influence on yield of cabbage crop under Manipur Valley. J Entomol Zool Stud. 5: 1546-1551.

Ashwini Ananda AK, Bijaya Devi, Singh A, Barik S, Bairwa MK. 2017. Cabbage (Brassica oleracea 1. var. capitata) cv. Rareball introduction with knol khol and broad bean intercropping: yield efficiency under foot hills of Imphal-west. Pharma Innovation J. 6: 339-341.

Bijaya P. 1998. Bioecology of Myzus persicae (Sulzer) (Homoptera: Aphididae) on certain cole crops of Manipur, Ph D thesis, Manipur University, India, 189 pp.

DAC. 2017. Govt. of India Horticulture Statistics at a glance. 197.

Charles C, Tatchell M, Williams CF. 1981. The comparative susceptibilities of Pieris brassicae and Pieris rapae to a granulosis virus from Pieris brassicae. $J$ Invertebr Pathol. 38: 273 - 280. https://doi.org/10.1016/00222011(81)90133-6

Crook NE. 1981. A comparison of the granulosis virus from Pieris brassicae and Pieris rapae. Virology 115: 173181. https://doi.org/10.1016/0042-6822(81)90099-4

Devjani P. 1999. Bio-ecology and control of insect pests of cauliflower in Manipur. Ph.D thesis, Manipur University, India, $189 \mathrm{pp}$.

Entwistle PF. 1998. World survey of virus control of insect pest- People of Republic China, In: pp. 258-268, Hunter FR, Fujita, Entwistle PF, Evans H Crook NE (Eds.). Insect Virus and pest management. John Willy and Sons, New York, USA.

Finney D. 1977. Probit Analysis. Cambridge University Press, London, UK, 333 PP. 
NIFTEM IFTEM \& MOFPI (2012-13): National Horticulture Production Database-2012-13, MOA \& Ministry of Food Processing Industries, GOI.

Rabindra RJ, Rajasekaran B, Jayaraj S. 1997. Combined action of NPV and neem bitter against Spodoptera litura (Fab.) larvae. J Biol Control 11: 5-9.

Sangeeta W. 2011. Studies on the virus infecting the cabbage butterfly, Pieris brassicae (Linn.) (Lepidoptera). Ph. D thesis, Manipur University, India, 187 pp.

Sangeeta W, Varatharajan R. 2011. Granulosis virus of the cabbage pest, Pieris brassicae - a potential biopesticide for the control of Pieris spp. (Pieridae: Lepidoptera). In: Pp 12. Ambrose DP (Ed.). Insect Pest Management, A Current Scenario. St. Xavier College, Palayamkottai, Tirunelveli, Tamil Nadu, India.

Sangeeta W, Ingobi M, Dhanapati K, Pandey RR, Varatharajan R. 2009. Pathogenecity of Pieris brassicae granulosis virus infecting the caterpillars of $P$. brassicae (Lepidoptera: Pieridae). In: Pp. 56-61. Ignacimuthu $\mathrm{S}$ and David BV (Eds.). Ecofriendly Insect Pest
Management. Elite Publishing House Pvt. Ltd., New Delhi, India.

Smith KM. 1976. Virus - Insect relationships. Longman Group Limited, 291 pp.

Shah BH, Zethner O, Gul H, Chaudhry MI. 1979. Control experiments using Agrotis segetum granulosis virus against Agrotis ipsilon (Lepidoptera: Noctuidae) on tobacco seedlings in northern Pakistan. Entomophaga 24: 393- 401. https://doi.org/10.1007/BF02374178

Varatharajan R. 2008. Augmentation and evaluation of PbGV viral pesticide for the control of the cabbage butterfly, Pieris brassicae (L.). DBT Project Final Report, New Delhi, India, 45 pp.

Zethner O, Khan BM, Ismail M, Chaudhry MI, Bolet B, Khan S, Khan HU, Gul H, Qgaard L, Zaman M, Gul Nawaz. 1987. Agrotis segetum granulosis virus as a control agent against field populations of Agrotis ipsilon and A. segetum (Lepidoptera: Noctuidae) on tobacco, okra, potato and sugar beet in Northern Pakistan. Entomophaga 32: 449-455. https://doi.org/10.1007/ BF02373513 